\title{
The International Financial Crisis: Eight Lessons for and from Latin America
}

\section{Liliana Rojas-Suarez}

\begin{abstract}
The international financial crisis of 2008-09 exposed the strengths and weaknesses of the current paradigm of development in Latin America, a paradigm based on liberalized capital accounts and significantly improved macroeconomic conditions. This paper presents lessons derived from the crisis, not only for the region itself, but also for other developing countries that might seek economic growth in the context of greater integration to the international capital markets. Some of the lessons are not new but have been reinforced by the crisis, such as Latin America's imperative need for export diversification (not only in products but in partners). Other lessons break with longstanding myths about the region, such as its inability to undertake counter-cyclical policies-at least on the monetary side. Yet other lessons reflect new developments in the current growth paradigm, such as a renewed assessment of (1) the relative roles of foreign and domestic banks in shielding the financial system against external shocks and (2) the potential costs of adopting blanket international financial regulations that do not account for a country's degree of development. Taken together, the lessons in this paper bring a new sense of optimism for growth in Latin America.
\end{abstract}

A final version of this paper will appear in the book tentatively titled New Ideas in Development after the Financial Crisis edited by Francis Fukuyama and Nancy Birdsall (forthcoming, The Johns Hopkins University Press). No part of this paper may be reprinted or reproduced electronically without the expressed permission of the Center for Global Development. All rights reserved 2010.

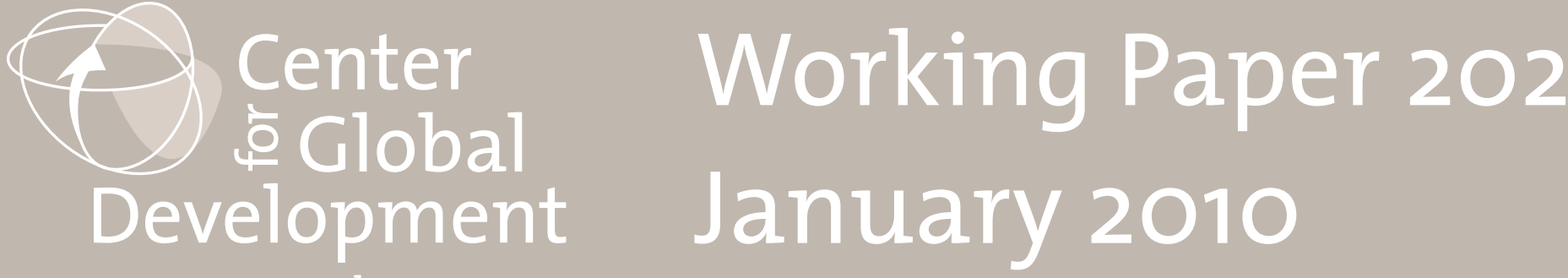




\title{
The International Financial Crisis: Eight Lessons for and from Latin America
}

\author{
Liliana Rojas-Suarez \\ Center for Global Development
}

The author is grateful for the valuable comments and suggestions from Nancy Birdsall, Seth Colby, and Francis Fukuyama and for the excellent research assistant support from Veronica Gonzales and Ted Collins. All remaining errors are the author's.

Liliana Rojas-Suarez. 2010. "The International Financial Crisis: Eight Lessons for and from Latin America.” CGD Working Paper 202. Washington, D.C.: Center for Global Development. http://www.cgdev.org/content/publications/detail/1423709

Center for Global Development 1800 Massachusetts Ave., NW Washington, DC 20036

202.416.4000

(f) 202.416 .4050

www.cgdev.org
The Center for Global Development is an independent, nonprofit policy research organization dedicated to reducing global poverty and inequality and to making globalization work for the poor. Use and dissemination of this Working Paper is encouraged; however, reproduced copies may not be used for commercial purposes. Further usage is permitted under the terms of the Creative Commons License.

The views expressed in this paper are those of the author and should not be attributed to the board of directors or funders of the Center for Global Development. 


\section{Introduction and Background}

Over the last century Latin America has not been short of ideas about development models. Indeed, some analysts have concluded that the region has tried it all: from a focus towards exports as a growth engine to massive tariffs and an inward bias, from large government interventions to a free market approach, and from autocracy to democracy. In spite of all these different approaches, Latin America has demonstrated a repeated pattern of intense economic volatility.

To be more exact, since the beginning of the twentieth century, there have been three distinct economic models for development. Two models have been overthrown, and the current model has been under intense criticism during the current decade. The trend of these overarching paradigms has been simple. An economic crisis has led to a new paradigm which slowly expanded its influence and universality; soon this paradigm took hold of the region, delivered marginal growth to countries, and generally began to show chronic problems; those problems turned into a crisis, which spurned a new paradigm shift. Now the most recent economic model, the model of open and deregulated markets, has been tested by the severe international financial crisis and a number of lessons can be derived from that experience. In contrast to previous crisis episodes, however, the region shows no intention of abandoning its most recent paradigm.

A brief history of the evolution of growth models in Latin America helps to understand current choices made by policymakers and to derive lessons for future decisions. ${ }^{1}$

The first model, known as the Export-Led Model was adopted during the period before the 1930's, when a swift progression of industrialization abroad translated into a greater global demand for Latin America's primary goods, like silver copper, wool, cotton, coffee, grain, and later oil. Based on the hypothesis that the region should specialize in the production of primary commodities, public policy was directed to protect the interests of exporters with disregard for improvements of social services, such as health and education. ${ }^{2}$ The model delivered growth during the 1920's. But as Latin American economies began to heavily specialize in specific raw materials, the model began to reveal weaknesses. The lack of diversification left the health of Latin American economies at the mercy of fluctuating commodity, food and raw material prices. These issues became chronic and irreversible when the Great Depression occurred and the demand for primary goods abroad collapsed. As a result, external demand could no longer power the economic activity of the region. Policy makers began to look inward to their own domestic economy.

The next paradigm was Import Substitution Industrialization, or ISI. Under this new model, championed by Raul Prebisch, Latin America shifted its focus toward industrial production, with its own domestic market as the economic motor. The primary goals for ISI were to gain economic independence, to reduce vulnerability to external shocks like the great depression, and to create more employment at home. During this period, tariffs were raised on imported goods,

\footnotetext{
${ }^{1}$ See, Shixue (2001) and Sanchez-Anochea (2007) for further discussion of these development models.

${ }^{2}$ This model resulted in a dual economy, with a modern export sector and a severely underdeveloped "traditional sector" producing art crafts in the urban areas and non-export agricultural products in the rural areas.
} 
and governments implemented industrial stimulus to spurn the formation of factories and more sophisticated commercial industries.

This model initially was successful in that manufacturing grew as a percentage of the gross domestic product until the 1970's. But Import Substitution did not satisfy its goals, and it eventually failed for three reasons. Firstly, Latin America was still dependent on the West. Instead of buying finished manufactured goods, Latin America imported intermediate goods used for capital accumulation. And the region's economies were still significantly trading primary goods to industrialized countries. Secondly, ISI did not create enough jobs. Latin America countries did not integrate with each other effectively, and domestic demand was insufficient to allow for a dynamic market for manufactured products. Also states ran the industrialization, which meant limited innovation; this hampered industrial growth and employment. Thirdly, governments progressively accumulated large amounts of debt to finance the industrialization, especially during the 1970's, when the rise in oil prices motivated international banks to lend more aggressively to developing countries. During the 1970's, Latin America's foreign debt rose from $\$ 27$ billion to $\$ 231$ billion. In the 1980's, oil prices dropped, and Latin America lost the foundation that permitted such aggressive lending. In 1982, Mexico was the first to announce that it could no longer sustain its floating interest burden, and thus began the Debt Crisis of the 1980's and the well-known lost decade of the region.

The debt crisis that occurred in the 1980's marked the region's next economic shift, which was to the model of financial openness and deregulation. The crisis caused a maelstrom of problems for the Latin American people: hyperinflation, decreased income per capita, paralyzed markets, and minimal liquidity. Latin American economies could no longer sustain their debt burdens; a number of governments had defaulted on their loans, and they needed to negotiate with advanced industrialized economies, namely the United States, in order to minimize the economic damage. A solution was found in the Brady plan (which began in 1989 in Mexico), that allowed for the securitization of governments' external debt liabilities and for the creation of a highly liquid market for international bonds and other securities issued by the region. Debt securitization facilitated the region's increased access to international markets but was by no means a panacea.

With very low domestic saving ratios and extremely volatile terms of trade (resulting from export concentration in commodities), most Latin American countries liberalized their capital accounts seeking to support their development efforts with capital inflows, especially with foreign direct investment. In sharp contrast with the ISI model, the private sector was seen as the motor of growth. Also, in contrast to both the export-led and the ISI models, the central role of the government was to facilitate competition and the workings of the market economy rather than picking winners (primary commodities under the export-led model or the manufacturing sector under the ISI model).

But, under the new paradigm, greater financial openness implied a policy decision to let market forces, through the behavior of the international capital markets, assess the performance of the economy. This in turn required that macroeconomic stability needed to be maintained at all times, since deterioration in investors' perception about a country's creditworthiness would result in a quick reversal of capital inflows. Moreover, the sustainability of financial openness required adequate regulation and supervision of the domestic financial system to avoid excessive risk- 
taking activities that might have compromised the maintenance of both financial and macroeconomic stability.

During the 1990s the process of financial liberalization continued and, as shown in Chart 1, by the early 2000s Latin America was the most financially open region in the developing world, second only to industrial countries. ${ }^{3}$

\section{Chart 1}

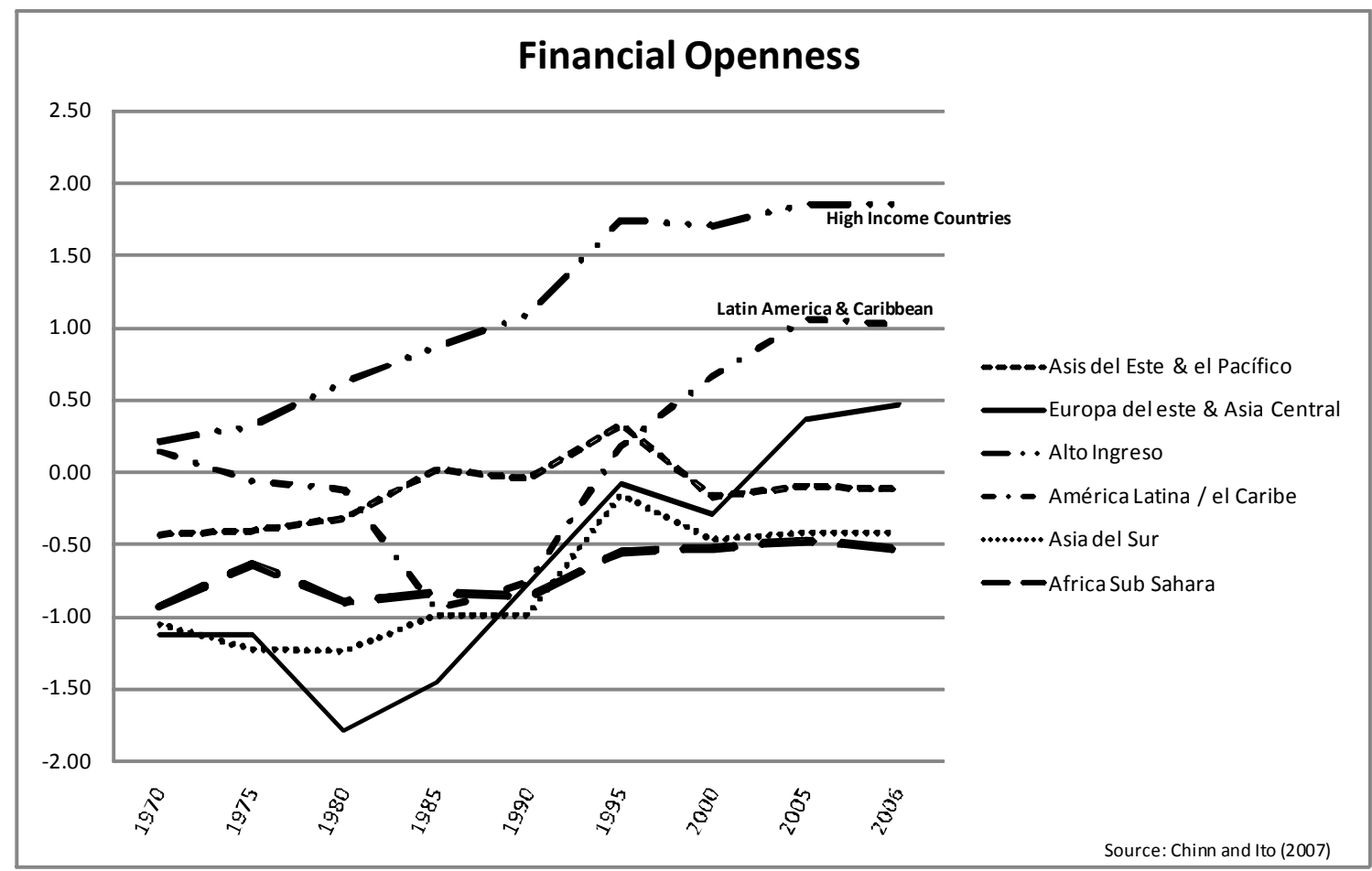

However, during the 1990's the requirements for sustainable open capital accounts were not followed in a number of countries in the region. Lacking adequate financial supervision and macroeconomic stability, a fresh round of economic and financial crises plagued the region. These started with Mexico's Tequila crisis in the mid-1990s, when unsustainable macroeconomic conditions induced a sharp reversal of capital flows. Crisis countries also included Colombia (1998), Argentina (1994, 2001), Venezuela (1994), Brazil (1999), Ecuador (2001), Uruguay (2001) and Dominican Republic (2002). The few countries, like Chile and Peru that managed to avoid deep economic imbalances also did not experience economic and financial crises. To the critics of the open capital account model, these crises revealed the weakness of subjecting countries to the vagaries of international capital markets.

But rather than abandoning the new paradigm of growth based on liberalized capital accounts, the crises of the 1990's and early 2000's led most governments in the region to improve the

\footnotetext{
${ }^{3}$ The index of financial openness by Chinn and Ito (2007) takes higher values the more open the region is to crossborder capital transactions.
} 
policies that would allow for the sustainability of this model. There were (and are) some wellknown exceptions, notably Ecuador and Venezuela. ${ }^{4}$

Supported by improved policies and a positive international environment, Latin American economies grew once again starting in 2003 and this time for five consecutive years at annual average regional rates above 4 percent, an outcome not seen since the 1970's. However, not even a return to high growth was able to induce strong support for further comprehensive marketbased reforms. An important reason behind this reticence was that large segments of the population did not feel included in the benefits from growth. The result of this thinning of patience with the current growth model has been a significant slowdown of the process of structural reforms in most countries in the region.

Notwithstanding these developments, reports of a generalized political backlash against the market economy and market-oriented reforms need to be taken with caution. Although some countries have elected leftists or center-leftists leaders, there are drastic differences in ideology and governance between for example the current government of Venezuela and that of Brazil and Uruguay. Also, the coalition in Chile has successfully been able to deal with social demands.

As the recent international crisis erupted in 2007 and later progressed during 2008-09, Latin American countries with open capital accounts did not impose capital controls to the outflows, even though the reversal of inflows from the region was severe. At the time of this writing, the generalized assessment about Latin America's management of the crisis was quite positive, albeit with important caveats. ${ }^{5}$

The rest of this paper presents lessons derived from the experience of Latin America during the recent international crisis. As the title of the paper indicates, some are lessons for the region, but others are lessons from Latin America to other developing countries that might seek to achieve growth in the context of greater integration to the international capital markets, such as Eastern Europe now and maybe Africa in the future. Based on the Latin American experience, countries tend to abandon development paradigms that prove to be economic, politically and socially unsustainable. Given the good performance of Asian countries during the recent international crisis (and the quick recovery of the region during its own crisis in the late 1990s), a shift of Asian countries towards a very open financial system a la Latin America is quite unlikely in the foreseeable future. ${ }^{6}$

\footnotetext{
${ }^{4}$ Argentina also belonged to this group for a long time; but at the time of this writing the country is trying to get renewed access to the international capital markets, including through negotiations to deal with unresolved issues from the debt default of the early 2000s.

${ }^{5}$ In late 2009, inflows to a number of Latin American countries recovered. Facing uncertainties about the sustainability of the recovery and the potential excessive appreciation of the real exchange rate, Brazil imposed limited controls on short-term portfolio inflows (foreign direct investment constitutes the lion's share of inflows to Brazil and this form of inflows was not subjected to controls). At the time of this writing it was too early to make an assessment about the effectiveness of the controls or the government's timeline regarding the maintenance of the controls.

${ }^{6}$ In the view of the author, there is no such a thing as an ideal development model for all regions of the world as economic and political conditions differ significantly across regions. Moreover, existing paradigms evolve over time as those conditions change. Although a comparison between different development models is way beyond the scope of this paper, there are neither signs no incentives for important convergence between the Asian model (high saving
} 
Although there are many lessons from the crisis, the analysis here focuses on eight selected ones, all of them related to the central issue of this paper: the sustainability of the open-capital-account model of growth in Latin America. Some lessons are not new, but are reinforced by the crisis. An example is the imperative need for export diversification in the region; this lesson is a century old. Some others break with myths, such as the region's inability to undertake counter-cyclical policies. Yet others reveal some new aspects of the region's development process, such as a renewed assessment of the roles of domestic public banks and foreign banks. All of them taken together bring a new sense of optimism towards the region.

\section{Lesson 1: Because of a shifting geo-economic international landscape accentuated by the crisis, it is more important than ever for Latin American countries to increase their trade diversification, not only in products but also in partners.}

For a very long time, the strong economic interconnections between Latin America and the United States have been characterized in a poignant saying: "If the United States gets a cold, Latin America gets pneumonia". However, while the United States is still a key trading partner for Latin America (and the most important contributor of foreign direct investment to the region $^{7}$ ), its share in total exports has declined significantly over the last 15 years. This demonstrates the increasing importance of new economic powers, as a number of Latin American countries have increased exports to new regions, especially China and other Asian countries.

Table 1 shows this trend by comparing the direction of exports by Latin American countries between 1992 and 2007. With the exception of Mexico (which has increased its share of exports to the US) and Venezuela (which has kept this share constant), Latin American countries have favored a larger participation of Asia and/or intra-regional trade. ${ }^{8}$

ratios, less open capital account) and the Latin American model. While, most likely, both regions could benefit from certain aspects of the alternative model, an adequate assessment of that issue requires a separate paper.

${ }^{7}$ See ECLAC, 2009

${ }^{8}$ Uruguay has slightly increased the US share in its exports, but from very low levels. 
Table 1

Direction of Exports by Trading Partners

(1992-2007)

\begin{tabular}{|c|c|c|c|c|c|c|c|c|c|c|}
\hline & \multicolumn{2}{|c|}{ Latin America } & \multicolumn{2}{|c|}{ United States } & \multicolumn{2}{|c|}{ Europe } & \multicolumn{2}{|c|}{ Asia } & \multicolumn{2}{|c|}{ Rest of the World } \\
\hline & 1992 & 2007 & 1992 & 2007 & 1992 & 2007 & 1992 & 2007 & 1992 & 2007 \\
\hline Argentina & 33.52 & 41.37 & 10.75 & 7.58 & 34.60 & 21.18 & 13.35 & 21.37 & 7.79 & 8.50 \\
\hline Bolivia & 39.88 & 62.39 & 16.02 & 8.82 & 41.10 & 11.17 & 1.67 & 14.26 & 1.33 & 3.35 \\
\hline Brazil & 22.43 & 24.10 & 19.34 & 15.58 & 32.64 & 29.47 & 18.93 & 19.71 & 6.66 & 11.14 \\
\hline Chile & 17.33 & 16.88 & 15.37 & 13.01 & 32.10 & 26.36 & 33.11 & 41.02 & 2.10 & 2.73 \\
\hline Colombia & 27.20 & 36.04 & 36.19 & 35.28 & 28.87 & 19.33 & 4.74 & 6.00 & 3.01 & 3.35 \\
\hline Costa Rica ${ }^{a}$ & 22.06 & 26.10 & 41.33 & 33.91 & 29.04 & 15.53 & 1.86 & 21.86 & 5.71 & 2.61 \\
\hline Ecuador & 19.00 & 32.98 & 45.65 & 43.12 & 17.09 & 16.57 & 15.89 & 2.83 & 2.37 & 4.50 \\
\hline El Salvador ${ }^{b}$ & 48.95 & 65.85 & 30.54 & 19.57 & 16.20 & 11.32 & 1.66 & 1.97 & 2.66 & 1.30 \\
\hline Guatemala $^{\mathrm{b}}$ & 41.05 & 53.13 & 37.30 & 25.38 & 13.29 & 7.47 & 4.32 & 8.38 & 4.03 & 5.64 \\
\hline Honduras $^{\mathrm{b}}$ & 11.23 & 29.97 & 55.96 & 42.66 & 26.74 & 20.61 & 4.34 & 4.20 & 1.73 & 2.56 \\
\hline Mexico & 5.01 & 6.03 & 80.71 & 82.28 & 7.82 & 5.41 & 3.07 & 2.79 & 3.39 & 3.49 \\
\hline Nicaragua ${ }^{b}$ & 29.52 & 48.15 & 41.41 & 27.49 & 17.53 & 14.93 & 0.64 & 2.97 & 10.91 & 6.46 \\
\hline Paraguayc ${ }^{c}$ & 48.43 & 59.51 & 5.33 & 3.27 & 36.44 & 19.82 & 4.75 & 5.55 & 5.05 & 11.84 \\
\hline Peru & 19.02 & 20.93 & 20.70 & 18.02 & 34.34 & 27.32 & 20.49 & 25.72 & 5.45 & 8.01 \\
\hline Uruguay $^{b}$ & 51.02 & 40.72 & 9.07 & 10.97 & 22.82 & 24.02 & 14.60 & 11.32 & 2.49 & 12.97 \\
\hline Venezuela & 17.97 & 23.46 & 52.31 & 52.40 & 11.25 & 13.18 & 3.84 & 2.01 & 14.63 & 8.95 \\
\hline
\end{tabular}

Based on this pattern, it is not surprising that Mexico is the most affected by the international crisis with a projected negative growth rate of over 7 percent in 2009. In terms of trade partners, Mexico is by far the most concentrated country in the region: over 80 percent of its exports are directed to the United States.

In contrast to Mexico, the most diversified countries in the region in terms of trade partners are Brazil, Costa Rica, Chile and Peru. Brazil, Chile and Peru in particular are actively seeking new bilateral trade partners in Asia and within Latin America. As discussed by Birdsall and RojasSuarez (2002), both the movement towards open regionalism and the inclusion of Asian partners, grant these countries greater access to the global system. Diversification has served these countries well during the international financial crisis.

Unfortunately not all Latin American countries favor free trade. The leaders of a group of countries have raised their voices against globalization and have increased protectionist impediments to global trade with measures such as increased tariffs and other protectionist measures. The key countries in this group (Argentina, Ecuador and Venezuela) each have differing degrees of protectionist measures and anti-market policies. Economic indicators for these countries before the international crisis show a very poor performance, with extremely high inflation in Argentina and Venezuela and severe fiscal problems in Ecuador. For this group of countries, it is fair to say that the international crisis simply exacerbated economic fragilities already rooted in the pre-crisis period.

While many Latin American countries are diversifying trade partners, they are not sufficiently diversifying the products to be exported. Table 2 presents an indicator of export concentration: the Herfindahl-Hirschman Index. As noted by Foxley (2009) exports in Latin America remain highly specialized in primary goods, with the extreme being Venezuela, which basically exports a single commodity: oil. In contrast, East Asian and Eastern European countries have been able 
to achieve greater diversification, moving forward in the value added chain by increasing their production of manufacturing goods. In the case of Latin America, increased diversification into both manufacturing and services is highly desirable. ${ }^{9}$

Table 2

\begin{tabular}{l|c}
\multicolumn{2}{c}{ Export concentration Index, 2006 } \\
\hline \multicolumn{1}{c}{ Exporting Region or Country } & Herfindahl-Hirschman Index \\
\hline Latin America & 31 \\
Chile & 39 \\
$\quad$ Venezuela & 91 \\
East Asia & 21 \\
Eastern Europe & 13 \\
\hline Source: Foxley (2009) based on World Bank 2008 \\
Note: The Herfindahl-Hirschman Indexis a measure of the degree of export concentration within a \\
country. The values of the Herfindahl-Hirschman Indexrange between 0 for no concentration and 100 \\
for maximum concentration
\end{tabular}

Although diversification in export partners has helped Latin America to deal with the current international crisis, the region has not yet learned a central lesson from previous crises, namely that the high volatility of commodity prices makes the region extremely vulnerable to external shocks. After all, the export-led model of the beginning of the last century was abandoned precisely because of plummeting commodity prices during the Great Depression, and the debt crisis of the 1980s was preceded by a collapse in the price of oil (a commodity exported by a number of countries in the region). This time around, Latin America's terms of trade fell sharply at the peak of the crisis in early 2009. Had that trend continued, the emphasis of the discussion in this paper would have been different.

\section{Lesson 2: Increased flexibility of exchange rates in the context of inflation targeting is the right policy choice for Latin America}

In contrast to previous crises episodes over the last three decades, contagion from the global financial crisis of 2007-2009 did not result in exchange rate crises across Latin American countries. Central banks were not forced to abandon their announced exchange rate regime after costly and ineffective efforts to defend an established exchange rate parity or exchange rate band. Just recall the sharp devaluations of the early 1980s throughout the region that ended with periods of extremely high or hyperinflations; or the abandonment of Brazil's crawling peg in 1999 following contagion from the Russian crisis, or the dramatic abandonment of Argentina's 10 -year-old currency board in 2002.

For a change, there was no drama on the exchange rate front in Latin America during the late 2000 s global crisis. This in spite of nominal exchange rate depreciations of around 30 percent in a number of countries (such as Chile, Colombia and Brazil) during the peak of the crisis (see Chart 2).

\footnotetext{
${ }^{9}$ Recent evidence shows that the effects of exchange rate changes on the profitability and competitiveness of the manufacturing sector are similar to the effects on services (see, for example, Baggs et al, 2008). The fundamental reason is that firms engaged in the production of services rely on manufacturing and primary goods inputs. In Latin America, the export of tourism and tourism-related services is a good example.
} 


\section{Chart 2: Exchange rate behavior in selected countries}
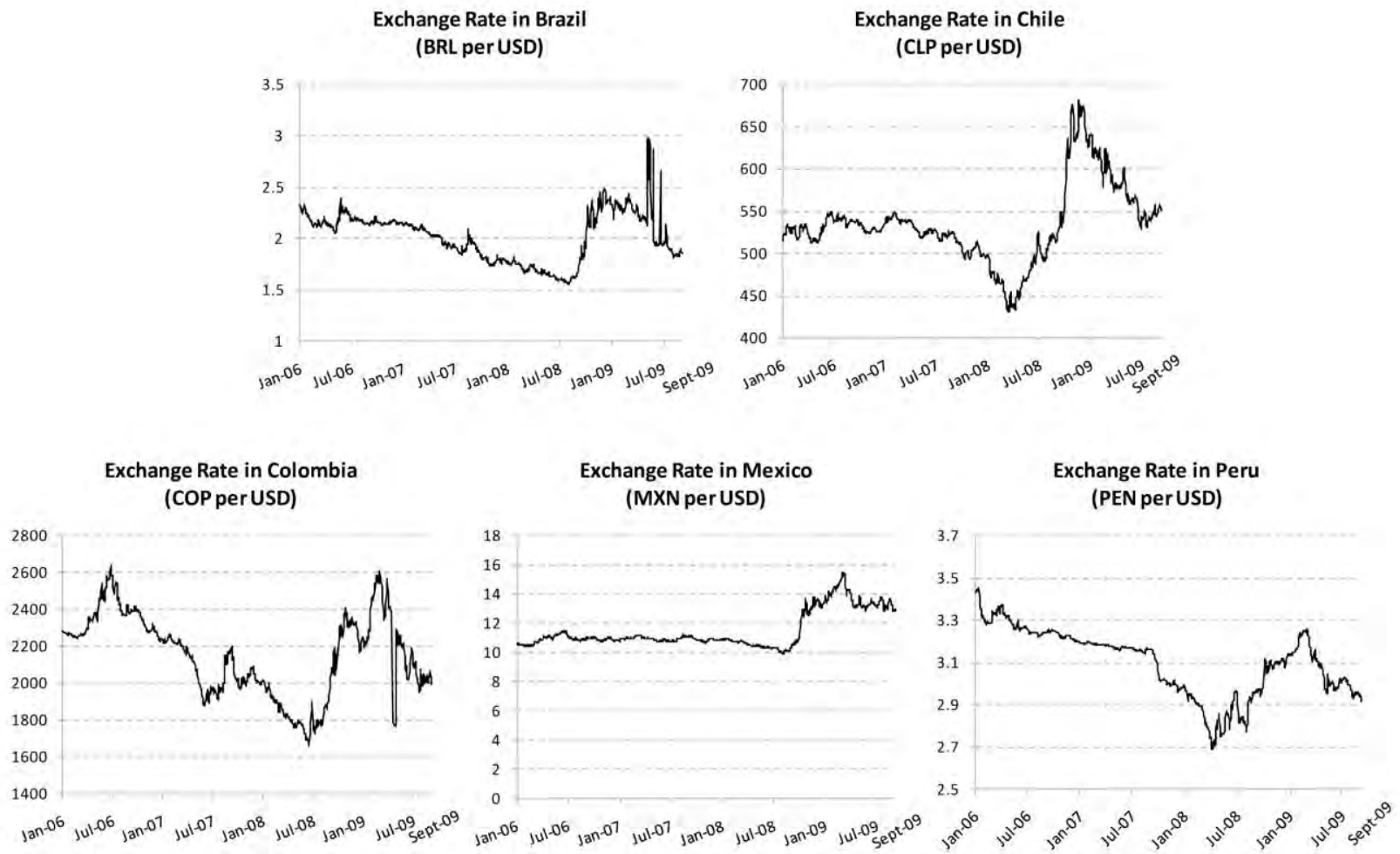

What was different? The answer is that by the early 2000s a large number of countries in Latin America had adopted more flexible exchange rate regimes. In addition, a number of central banks had chosen to combine more flexible exchange rate regimes with inflation targeting. ${ }^{10}$ The truth of the matter is that after recurrent episodes of crises, most Latin American countries learned an important lesson: having chosen to maintain a liberalized capital account, it is extremely difficult to simultaneously have both an independent monetary policy and a fixed exchange rate system. This derives from the well-known proposition of the so-called Impossible Trinity (i.e., the impossibility of simultaneously fixing the exchange rate, setting domestic interest rates, and having perfect capital mobility).

Actually, most of the previous exchange rate crises of the 1990s in Latin America followed a similar pattern. An external adverse shock materialized (such as a deterioration in the region's terms of trade or an increase in the external funding costs). This was followed by a sharp reversal of capital inflows to the region which put upward pressure on the exchange rate. To defend the peg, central banks increased interest rates and allowed foreign exchange reserves to decline. Because debt ratios were high in the region (see discussion above), it was straightforward for speculators to conclude that the country would have to abandon the exchange rate peg and,

\footnotetext{
${ }^{10}$ Exceptions to the movement towards increased exchange rate flexibility are Ecuador, El Salvador and Panama, which have adopted dollarization and most other Central American countries which actively manage their exchange rate.
} 
therefore, sharply bet against the maintenance of the announced peg ${ }^{11}$. The speculation itself led to further losses of foreign exchange reserves to a point where it was clear to governments that they could not longer sustain the exchange rate peg. This process was known as one-sided bet, implying that speculators always won in the bet against the parity.

No one-sided bets took place during the recent global financial crisis. ${ }^{12}$ Since most countries in the region were not committed to a peg or a band, central banks let the exchange rate depreciate when capital inflows to the region reversed sharply in late 2008-early 2009. Most importantly, because monetary policy was not restricted by the behavior of the exchange rate, most central banks were able to undertake counter-cyclical monetary policies. Thus, in sharp departure from their behavior in previous crises episodes, central banks lowered interest rates significantly in the midst of the crisis. This is shown in Chart 3 for a group of countries in the region. The expansionary monetary policies helped to provide necessary liquidity to domestic financial systems, and therefore it helped to ameliorate the adverse impact of the shock on local credit. Because the external shock implied a contraction in global demand, the expansionary monetary policies were consistent with the maintenance of the low inflation targets in many countries in the region. $^{13}$

\footnotetext{
${ }^{11}$ The depletion of foreign exchange reserves reduced the country's capacity to repay its outstanding external obligations. This was compounded by increased domestic interest rates to defend the exchange rate parity since higher interest rates also increased the financing cost of domestic debt.

${ }^{12}$ Ecuador and El Salvador, two of the dollarized countries in the region suffered important pressures on their exchange rate systems and discussions about a possible abandonment of dollarization in Ecuador are now an important component of the economic debate in Ecuador.

${ }^{13}$ Not all countries in the region have been able to keep inflation low, being Argentina and Venezuela the most noticeable examples. In these two cases, however, inflation rates were on an upward trend even before the start of the global financial crisis, and, thus, mostly reflect important macroeconomic imbalances.
} 


\section{Chart 3}

\section{Inflation and Interest Rate in Selected Latin American Countries}
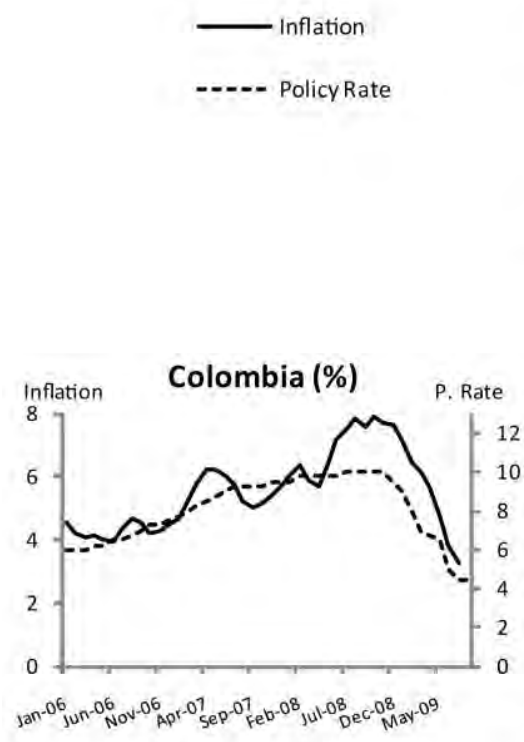

Source: Central Bank
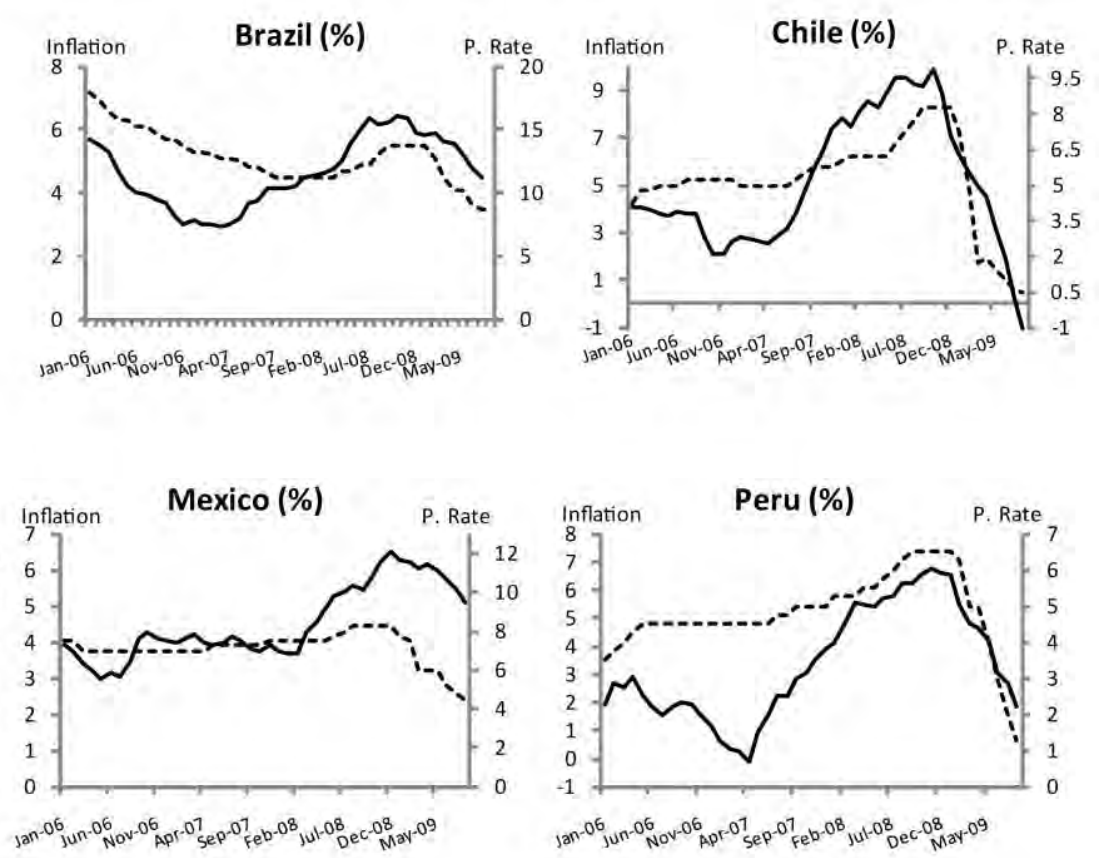

This lesson from Latin America is applicable to other countries in the developing world, especially those in Eastern Europe. Having liberalized their capital account, a number of countries in this group were among the most affected during the crisis precisely because they were committed to fixed exchange rate systems (Latvia, Ukraine and Belarus are vivid examples of this problem).

\section{Lesson 3: Lacking the capacity to issue hard currencies, accumulating large stocks of international reserves and implementing other forms of insurance against volatility is highly desirable.}

To economists, a policy of pursuing both flexible exchange rates and the accumulation of foreign exchange reserves appears contradictory. After all, the idea is that in a flexible exchange rate system, movements in prices (the exchange rate) and not in quantities (foreign exchange reserves) do the adjustment following a shock (positive or negative). This assessment is correct and that is why the previous lesson talks about increased rather than pure flexibility of exchange rates. The restrictions imposed by the volatility of capital inflows to Latin America imply that a pure flexible exchange rate system cannot adequately contribute to economic and financial stability. 
A major reason is that when foreign inflows to Latin America suddenly cease, even a sharp depreciation of the exchange rate cannot generate sufficient resources (through export revenues) quickly enough to meet due external amortization and interest payments. Now, if we were talking about industrial countries with the capacity of issuing fully tradable and liquid currencies (like the US dollar, the yen, the Euro, the British Pound, etc), the countries would issue liquid external liabilities that would be used to service debt payments (at a depreciated exchange rate, of course). But developing countries in general, and Latin America, in particular, cannot issue hard currency; thus it is fully appropriate to accumulate large amounts of foreign exchange reserves in good times to deal with the vagaries of international capital markets. ${ }^{14}$

This is what many Latin American countries did in the years prior to the international financial crisis. A good measurement of the adequacy of net foreign exchange liquidity is the ratio of short-term debt to international reserves. The lower the ratio is, the greater a country's ability to meet due external payments in the presence of an adverse shock. Table 3 shows this ratio for a number of emerging market economies. By 2008, Poland and Hungary displayed the highest ratio among the countries in the sample, and were therefore, the most vulnerable countries to an external shock, according to this indicator. In contrast, most countries in Asia and Latin America displayed much lower ratios and were, therefore, in a better footing to face the crisis. ${ }^{15}$

Table 3

\begin{tabular}{lcc}
\multicolumn{2}{c}{ Short Term External Debt / International Reserves (\%) } & in Selected \\
\hline \multicolumn{1}{r}{ Country } & $\mathbf{2 0 0 7}$ & $\mathbf{2 0 0 8}$ \\
\hline Argentina & 85.33 & 75.21 \\
Brazil & 21.57 & 23.01 \\
China & 14.42 & 14.70 \\
Colombia & 24.63 & 26.04 \\
Ecuador & 59.89 & 31.36 \\
Hungary & 88.00 & 81.92 \\
India & 11.43 & 17.89 \\
Indonesia & 28.67 & 30.72 \\
Malaysia & 13.81 & 24.95 \\
México & 45.08 & 49.24 \\
Perú & 20.97 & 19.71 \\
Phillippines & 23.93 & 21.49 \\
Poland & 74.71 & 82.68 \\
Taiwan & 30.80 & 32.22 \\
Venezuela & 27.29 & 22.09 \\
\hline
\end{tabular}

Source: Deutsche Bank

\footnotetext{
${ }^{14}$ A policy of accumulating foreign exchange reserves implies that pure floating is not possible. Instead, managed floating is the recommended policy option. This involves a combination of rules and limited discretion. An important rule is that central banks cannot intervene to continuously smooth exchange rate fluctuations. The discretion is that, sporadically, central banks can intervene in the foreign exchange market to manage their international liquidity position. See Rojas-Suarez (2003) and Goldstein (2002) for further elaboration on this issue. ${ }^{15}$ Chile and Mexico were in intermediate positions between the best and the worst self-insured countries. By the end of 2008-beginning of 2009 Chile corrected its deficiency of foreign exchange reserves by sharply intervening in the foreign exchange market inducing a sharp depreciation of its exchange rate.
} 
A related lesson, learned by most Latin American countries before the crisis, but not by countries in Eastern Europe is that large current account deficits tend to be unsustainable in countries that cannot issue hard currencies (unless they hold extremely high stocks of foreign exchange reserves, with a punitive opportunity cost). The lesson learned from recurrent balance of payments crisis in Latin America is that it does not matter significantly if the large current account deficit is generated by the public or private sector. If an adverse external shock leads investors to increased risk aversion, emerging markets with large current account deficits will face significant problems in rolling-over existing maturing debt and in acquiring new ones. As explained above, a central reason is that, lacking the capability to issue a liquid international currency, investors' increased risk aversion will induce a portfolio shift away from emerging markets' debt and toward the holding of liabilities issued by safer issuers. At this point experience shows that to avoid large private sector bankruptcies, governments will absorb important fractions of private sector debt in their books. That is why in emerging markets private debt is often a contingent liability of the public sector. ${ }^{16}$

Table 4 illustrates the sharp differences in balance of payments positions between the emerging markets regions of the world. While Latin America and East Asia faced the beginning of the international crisis with positive current account balances, Eastern Europe's external position was extremely fragile. While countries in Eastern Europe built up large stocks of external debt, in the years previous to the crisis a number of Latin American countries bought back expensive debt and improved the maturity profile of their debt obligations. As noted by Foxley (2009), Eastern European countries' accession to the European Union gave them a false sense of security regarding their ability to enjoy continuous access to international capital markets. Self-insurance through accumulation of foreign reserves was extremely low when the crisis started.

\footnotetext{
${ }^{16}$ Although the recent large bail outs of private financial and non-financial corporations in the US and other industrial countries suggests the statement is valid not only for emerging markets but in the recent case even for the world's most creditworthy countries.
} 
Table 4

Current Account and Debt Ratios by Regions and Selected Countries

\begin{tabular}{|c|c|c|c|}
\hline \multirow[t]{2}{*}{ Region } & \multicolumn{2}{|c|}{$\begin{array}{l}\text { Current Account as } \\
\text { Percentage of GDP } \\
\text { (annual average) }^{a}\end{array}$} & \multirow[t]{2}{*}{$\begin{array}{c}\text { Ratio of External } \\
\text { Debt to GDP, } 2008 \\
\text { (percent) }^{\text {b }}\end{array}$} \\
\hline & 2003-2007 & $2008-2010^{F}$ & \\
\hline Eastern Europe & -9.2 & -7.2 & 89.4 \\
\hline Bulgaria & -13.61 & -13.42 & 66.46 \\
\hline Czech Republic & -3.73 & -2.92 & $\mathrm{n} / \mathrm{a}$ \\
\hline Hungary & -7.58 & -5.07 & 95.36 \\
\hline Latvia & -15.72 & -8.45 & 113.32 \\
\hline Poland & -2.95 & -4.63 & 37.15 \\
\hline Romania & -9.46 & -8.89 & 45.32 \\
\hline Slovak Republic & -6.95 & -5.67 & 49.20 \\
\hline Latin America & 2.7 & -0.9 & 26.6 \\
\hline Argentina & 2.80 & 1.39 & 57.03 \\
\hline Brazil & 1.09 & -1.81 & 18.19 \\
\hline Chile & 2.32 & -3.94 & 32.90 \\
\hline Colombia & -1.56 & -3.33 & 25.88 \\
\hline Ecuador & 0.77 & -1.15 & 39.94 \\
\hline Mexico & -0.70 & -2.04 & 19.15 \\
\hline Peru & 0.86 & -3.26 & 30.49 \\
\hline Venezuela & 13.83 & 5.32 & 24.54 \\
\hline East Asia & 7.5 & 6 & 32 \\
\hline Phillipines & 2.75 & 2.14 & 51.31 \\
\hline Indonesia & 1.91 & -0.34 & 35.90 \\
\hline Malaysia & 14.23 & 13.67 & 34.86 \\
\hline Taiwan & 7.33 & -4.63 & $\mathrm{n} / \mathrm{a}$ \\
\hline \multicolumn{4}{|c|}{ Source: a. WEO - IMF 2009. b. WDI - WB 2008 and Foxley (2009) } \\
\hline \multicolumn{4}{|c|}{$\begin{array}{l}\text { Note: the regional averages do not correspond to the average of the few selected } \\
\text { countries in each region }\end{array}$} \\
\hline
\end{tabular}

But it is important to note that while a large accumulation of foreign exchange reserves is a good mechanism for self-insurance against highly volatile capital flows, this is a very costly alternative, and ideally countries would have access to other mechanisms that would substitute partially for reserves. ${ }^{17}$ There are a number of other market instruments that could help countries acquire much needed hedging. These instruments include contingent lines of credit with foreign private financial institutions and issuance of indexed bonds, either to GDP or commodity prices.

\footnotetext{
${ }^{17}$ As noted in Rojas-Suarez (2003) the benefits of accumulating foreign liquidity as a buffer to unexpected shocks need to be balanced against the cost of holding these assets, which are characterized by low returns. Indeed, an important problem in the consolidated government and central bank balances is the large interest rate differential between their debt liabilities and their liquid assets. As an additional policy to deal with unexpected shocks, in the 2000s many Latin American countries changed the profile of their external financial obligations, buying back expensive debt with near-term maturity and improving the overall term structure of their external debt. During the 1990 s, Chile lengthened the average term of external liabilities by taxing short-term inflows more heavily than longterm inflows.
} 
In a recent study, Perry (2009) recommends that multilateral organizations help developing countries issue these types of instruments. At this juncture however, we cannot say that this sensible recommendation has been a lesson learnt from the recent global financial crisis (more of this on lesson 8).

\section{Lesson 4: Fiscal stabilization funds are a must, especially in democratic and unequal Latin America}

In contrast to the effective counter-cyclical monetary policies undertaken by a number of countries in the region during the crisis, Latin America had difficulty implementing countercyclical fiscal policies. Only Chile and to some extent Peru were able to undertake fiscal stimulus without concerns about jeopardizing the dynamism and sustainability of their public debt. Even in Brazil, where an important fiscal expansion took place, there were important concerns about the ability of policymakers to reverse fiscal stimulus at the appropriate time (i.e. avoiding turning a countercyclical policy into a steady-state one), especially in the context of upcoming presidential elections in 2010.

Mexico clearly was incapable of undertaking counter-cyclical fiscal policies, which was demonstrative of most Latin America countries. Sharply affected by the global crisis, Mexico's fiscal revenues deteriorated significantly, which exposed unfunded financial needs. Efforts to support local governments affected by the recession took place in 2009 through the issuance of government bonds. These bonds further compromised the future fiscal stance as amortization and interest payments became due. Lacking a solid fiscal stance and facing a potential downgrade of its debt by the international credit ratings (which would increase external financing costs), the Mexican government submitted to Congress a fiscal proposal that included a severe fiscal adjustment. $^{18}$

Thus, the Mexican government will implement a pro-cyclical fiscal policy in 2010. As part of the proposal a new quasi-VAT tax will be implemented (VAT taxes are known for their regressive nature as they collect a higher proportion from the incomes of the poor than from those of the rich), and expenditure cuts will be reflected in the loss of a large number of public servants. Although increased revenue collections from the VAT are earmarked to protect social expenditures, the fiscal reform will most likely bring social unrest and further political fragmentation. These outcomes risk the stability of the market-led financially-open model of growth in Mexico.

In sharp contrast, Chile was capable of undertaking an active counter-cyclical fiscal policy without affecting its financing and its creditworthiness to international capital markets. This is because Chile follows a fiscal rule that allows it to save during good times (in the so-called Economic and Social Stabilization Fund--FEES) and increase expenditures during a crisis. The fiscal rule calls for achieving a targeted "structural fiscal balance", where a structural balance is defined as the difference between structural fiscal revenues and observed fiscal expenditures. Structural fiscal revenues are defined as the level of revenues that would have occurred if the output were at its potential level and the price of copper and derivatives were at their long-run

\footnotetext{
${ }^{18}$ In November 2009, Fitch downgraded Mexico's sovereign debt by one notch.
} 
level. ${ }^{19}$ This allows for a smoothing of fiscal revenues. In the years previous to the crisis, when the price of copper was high and output was growing fast, the fiscal authorities targeted a structural fiscal surplus. In 2009, when economic conditions deteriorated, the Chilean authorities were able to move to a structural fiscal deficit that was financed by past savings under the FEES.

Chile also used fiscal counter-cyclical resources to recapitalize the state-owned Banco Estado, Chile's Development Agency (CORFO) and the Insurance Fund for Small Enterprises (FOGAPE), to support credit to exporters, small enterprises and consumers. That is, the government was able to partially offset credit reductions from the private sector by channeling government funds through public banks. This encouraging development requires further analysis that goes beyond the scope of this paper, but there is a potential lesson from the Chilean experience. Public banks can play a crucial role in the direct provision of credit when the private banking sector needs to take a cautionary position due to adverse external circumstances and the extension of credit by public banks is fully funded. It is too early however, to derive long-term conclusions as a return to good times would need to be accompanied by a retrenching of credit activities by public banks to avoid crowding out of private sector financial institutions. ${ }^{20}$

\section{Lesson 5: Sound banks are a key shield against external shocks...but domestic rather than foreign banks might play a greater stabilizing role}

A lesson learnt the hard way by most Latin American countries is that weak banking systems are not compatible with open capital accounts. The 1980's and 1990's witnessed a large number of banking crisis episodes ignited by a sudden reversal of capital inflows to the region. As discussed above, a sudden stop of external funding leads to a depreciation of the exchange rate. It also exerts a downward pressure on economic activity as important projects (both from the public and private sector) meet funding constraints. The past has shown that these developments expose existing fragilities in the regions' banking systems.

Because of lax regulatory and supervisory frameworks during the 1980s and the 1990s, banks took excessive credit risk in good times. A rapid deceleration of economic activity in the face of a reversal of capital inflows resulted in a proliferation of bad loans and sharp losses of capital in already under-capitalized banking systems. Moreover, exchange rate depreciations exposed important currency mismatches in the system. In particular, a phenomenon known as liability dollarization was present in many countries in the region where both the US dollar and the local currency were used for financial transactions. ${ }^{21}$ Liability dollarization meant that banks were extending US-dollar denominated loans to borrowers whose income was denominated in local currency (most individuals and firms working in non-tradable sectors). A sharp depreciation of the exchange rate implied that these borrowers were not able to service their debts. The

\footnotetext{
${ }^{19}$ For a full description of how the Chilean rule operates see IDB (2008)

${ }^{20}$ In Brazil, the authorities also extended credit through the Brazilian Development Bank (BNDES). However, this is not surprising in this country since public banks play a large role in the financial system. In contrast, in Chile, public banks typically act as second tier banking.

${ }^{21}$ The use of US dollars in many Latin American countries started in the 1980s when huge devaluations and high or hyper inflation resulted in large losses in real wealth by holders of assets denominated in local currency.
} 
Argentina and Uruguay crises of the early 2000's were vivid examples of the problems associated with liability dollarization.

During the recent international crisis, exchange rates depreciated significantly (see lesson 2 above) and most countries faced recession. But breaking with the region's pattern, no banking crisis emerged. The fundamental reason for this was a combination of improved regulatory and supervisory standards (see lesson 6 below) along with improved risk-assessment mechanisms in a number of large banks in the region. Thus, as shown in Chart 4 , indicators of financial solvency in Latin America improved significantly in the 2000's. ${ }^{22}$ However in spite of these improvements, confidence in many of the region's financial systems has been far away from being restored. As a result, the ratio of deposits to GDP have remained extremely low in most countries (the regional average is below 30 percent) and this is consistent with the low private savings ratios observed throughout the region (see lesson 7 below).

\section{Chart 4}

\section{Financial Soundness Indicators in Latin America}

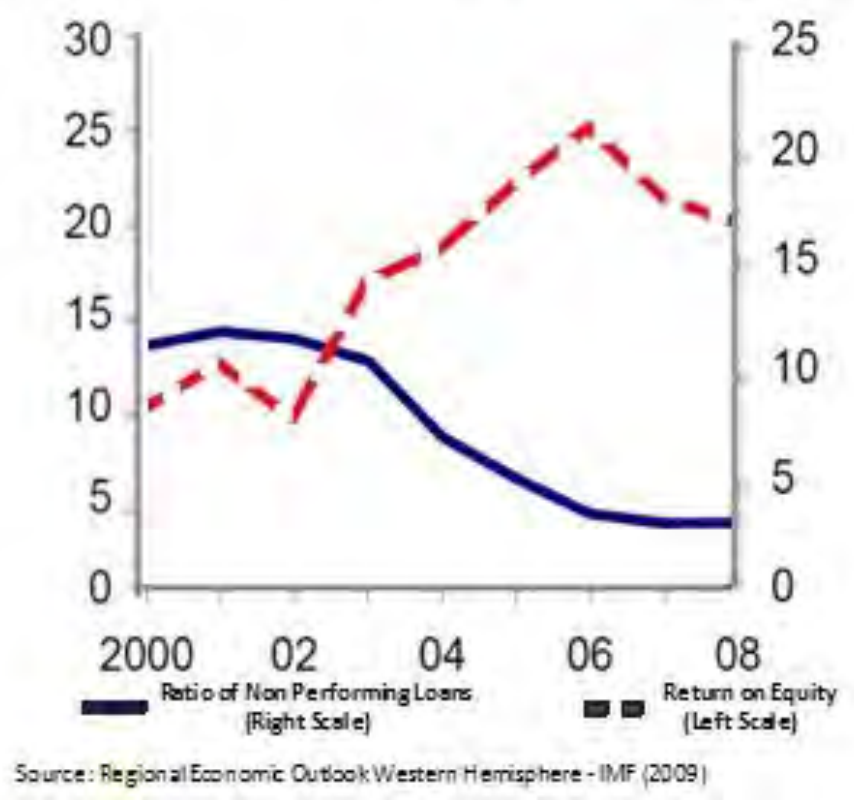

But a new, important lesson has also emerged from the recent crisis: banks that contribute to financial stability do not have to be foreign banks. To many readers, this could appear as an obvious statement. But as those familiar with the process of internationalization of the banking system in Latin America can testify, it is not.

The significantly increased participation of foreign banks in Latin America started in the mid1990's as a result of two factors, depending on the country. The first was that the process of liberalization of domestic financial systems together with the privatization of public banks drew

\footnotetext{
${ }^{22}$ See IMF (2009) for a comprehensive discussion of these issues.
} 
foreign investment into local banking systems. The second was that the need to recapitalize banking systems, in the context of severe banking crises, involved efforts to attract foreign capital into local banking systems. Albeit sharp differences between countries, participation of foreign banks in Latin America has been high. By 2007, foreign banks accounted for over 85 percent of total assets of the banking systems in Mexico and El Salvador, and the median value for the region was about 40 percent. $^{23}$

Foreign banks have brought significant benefits to the region. As documented in IDB (2005) the evidence shows that the increased participation of foreign banks has been associated with greater efficiency and improvements in risk-assessment techniques. However, while at the beginning of the process of internationalization, foreign banks displayed better financial indicators than local banks, that is not longer the case. By 2008, in many countries it was difficult to distinguish between domestic and foreign banks with respect to their financial soundness indicators, such as capitalization and liquidity ratios, return on assets and operating costs.

Moreover, a recent study by Galindo, Izquierdo and Rojas-Suarez (2009) shows that for most of the 2000's the response of bank credit to changes in economic activity has been as equally procyclical in foreign banks as in and in domestic banks. This has also been true during the recent international crisis. Facing a sharp reduction in economic growth, both foreign and domestic banks have reduced the expansion of credit. Thus, there appears to be some convergence in behavior between domestic and foreign banks. ${ }^{24}$

However, evidence also shows that foreign banks respond differently than domestic banks to external financial shocks. The results from Galindo, Izquierdo and Rojas-Suarez (2009) suggest that in the presence of an adverse (positive) external financial shock foreign banks reduce (increase) real credit growth and increase (reduce) real interest rates more than domestic banks. That is, foreign banks tend to amplify the impact of foreign financial fluctuations on domestic variables. Interestingly enough, the study also shows that origin matters and that Spanish banks behave more like domestic banks and do not amplify the impact of foreign shocks on credit and interest rates.

These results need to be taken with caution, especially since there are large differences across countries in the region. The challenge for policymakers is twofold. Firstly, encourage entry to the system of sound banks without a bias favoring foreign banks. ${ }^{25}$ Secondly, implement policies that preserve the gains of greater financial integration obtained through foreign banks while avoiding the excessive transmission of foreign financial shocks into domestic economies. The establishment of letters of agreement between domestic and foreign supervisors is a must. Interestingly enough, these agreements have already been signed with Spain, but have been difficult to obtain with a number of other industrial countries.

\footnotetext{
${ }^{23}$ The two clear exceptions are Ecuador (4.5\%) and Venezuela (1.8\%).

${ }^{24}$ As discussed in lesson 4, this development led governments from some countries to promote the expansion of credit by public banks.

${ }^{25}$ In the past, efforts to attract foreign banks were fully justified given the performance of domestic banks.
} 


\section{Lesson 6: Financial regulation in Latin America needs to be designed to meet the particular features of the region...not those of industrial countries}

Lesson 5 stressed the absence of severe banking difficulties in Latin America during the recent international crisis and attributed that result, at least partly, to improved regulation. But what type of financial regulation was (and is) in place in the region? Certainly not the new international Accord for bank capital requirements, better known as Basel II, since most supervisors were concerned about the complexities of the new Accord and were moving very slowly towards its implementation. This policy decision served the region well, especially since Basel II faced intense criticisms during the crisis by analysts in industrial countries. Some even listed Basel II (implemented in Europe) and Basel I (the standard in the United States) as major culprits for the eruption of the crisis.

The argument was that regulatory capital requirements not only were unable to improve banks' solvency but instead increased banks' incentives to take excessive risk. ${ }^{26}$ Two examples stand out: The first example is that Basel I created incentives for excessive mortgage securitization by banks in the United States because mortgage loans kept in bank's balance sheets carried a higher capital requirement than securitized loans kept off-balance sheets. The second example relates to the intensive use of credit rating agencies in Basel II. These agencies severely over-valued the quality of structured products and, therefore, played a major role in the build-up of the crisis.

As the Basel Committee for Banking Supervision revises Basel II and new proposals are advanced, one hopes that the needs of Latin America and other developing countries are taken into account. Ideally, regulation on banks should converge across countries to avoid regulatory arbitrage; namely, the shifting of bank operations towards those countries with less stringent regulation. In practice, however, the degree of development matters for the adequate design of adequate regulation. ${ }^{27}$ And that is an important lesson that needs to be learned from the international crisis.

First of all, in the least developed Latin American countries (such as many in Central America and Paraguay), solid accounting and reporting standards are not in place and enforcement of contracts is extremely weak. In this environment capital requirements become meaningless. This is because simple non risk-weighted bank capital is calculated by subtracting liabilities from assets. If, for example, non-performing loans were not adequately estimated, the calculated value of capital would also be wrong. Also in several of these countries, capital markets are incipient or non-existent; thus, there are no market signals that can complement the role of supervisors in assessing the quality of banks. For this group of countries, efforts need to be focused on establishing the appropriate legal, judicial and accounting frameworks before placing high expectations on the effectiveness of capital standards.

\footnotetext{
${ }^{26}$ See, for example a 2007 statements of the US Shadow Financial Regulatory Committee: http://www.aei.org/docLib/20071210 ShadowStatement253.pdf

${ }^{27}$ See Rojas-Suarez (2001 and 2004) for a detailed discussion on the constraints faced by developing countries in their use of capital adequacy standards as a supervisory tool.
} 
Second, for the relatively most developed countries in Latin America, where capital requirements can indeed be a useful supervisory tool, the challenge is to design the standard that works best for those countries, and Basel II does not seem to fit the bill. Neither the use of credit rating agencies nor the heavy reliance on the banks' internal models for risk assessment is useful. There is no regulation for credit rating agencies in these countries and supervisors do not have sufficient tools to evaluate the quality of banks' internal models. For this group of countries, a simple leverage ratio needs to be at the core of capital requirements.

Will the international setting-bodies arrive to this kind of conclusions when revising their proposed regulations? One can just hope that the increased role of the G-20 in the global landscape will play an important role in ensuring adequate recommendations for financial regulation in developing countries and that Latin America will benefit from that.

\section{Lesson 7: As in previous episodes of adverse external shocks, the global international crisis once again demonstrated that low savings rates are an important constraint for Latin America's development Model}

When comparing between different development models, a number of analysts question the desirability of relying on foreign capital inflows as a key engine for growth. As I hope has become evident throughout the discussion in this paper, it has not been easy for Latin American countries to ensure the sustainability of their market-led financially-open model. Nor has it been cheap, as accumulating large amounts of foreign exchange reserves entails important financial costs. However as discussed in the introduction, most Latin American countries have no intention to deviate from their chosen model. The fundamental reason is that domestic savings are extremely limited.

As the analysis in Birdsall and Rojas-Suarez (2004) shows, financing development relies on three major pillars: foreign financial flows, export revenues and domestic savings. As discussed above, the lack of diversification of export products implies that the region is subject to large terms of trade shocks mostly because of the large concentration on commodity exports, whose prices are extremely volatile. Thus Latin America cannot rely on export revenues to provide a steady source of finance. ${ }^{28}$

Latin America has made important progress toward maximizing the benefit from external sources of finance and toward minimizing the adverse consequences of a sudden reversal of inflows. But the region has not been successful in improving domestic savings ratios. Chart 5 shows a disheartening development. By 2006, the region as a whole displayed a ratio of national savings to GDP that was comparable to levels reached in the 1970s. While this regional ratio typifies well the representative Latin American country, there are two exceptions. The first is

\footnotetext{
${ }^{28}$ Although it is important to recognize that diversification in terms of trade partners is a move in the right direction.
} 
Chile, whose savings ratio has significantly increased. The second is the Central American region, with declining national saving ratios. ${ }^{29}$

\section{Chart 5}

\section{National Savings over GDP in Latin America}

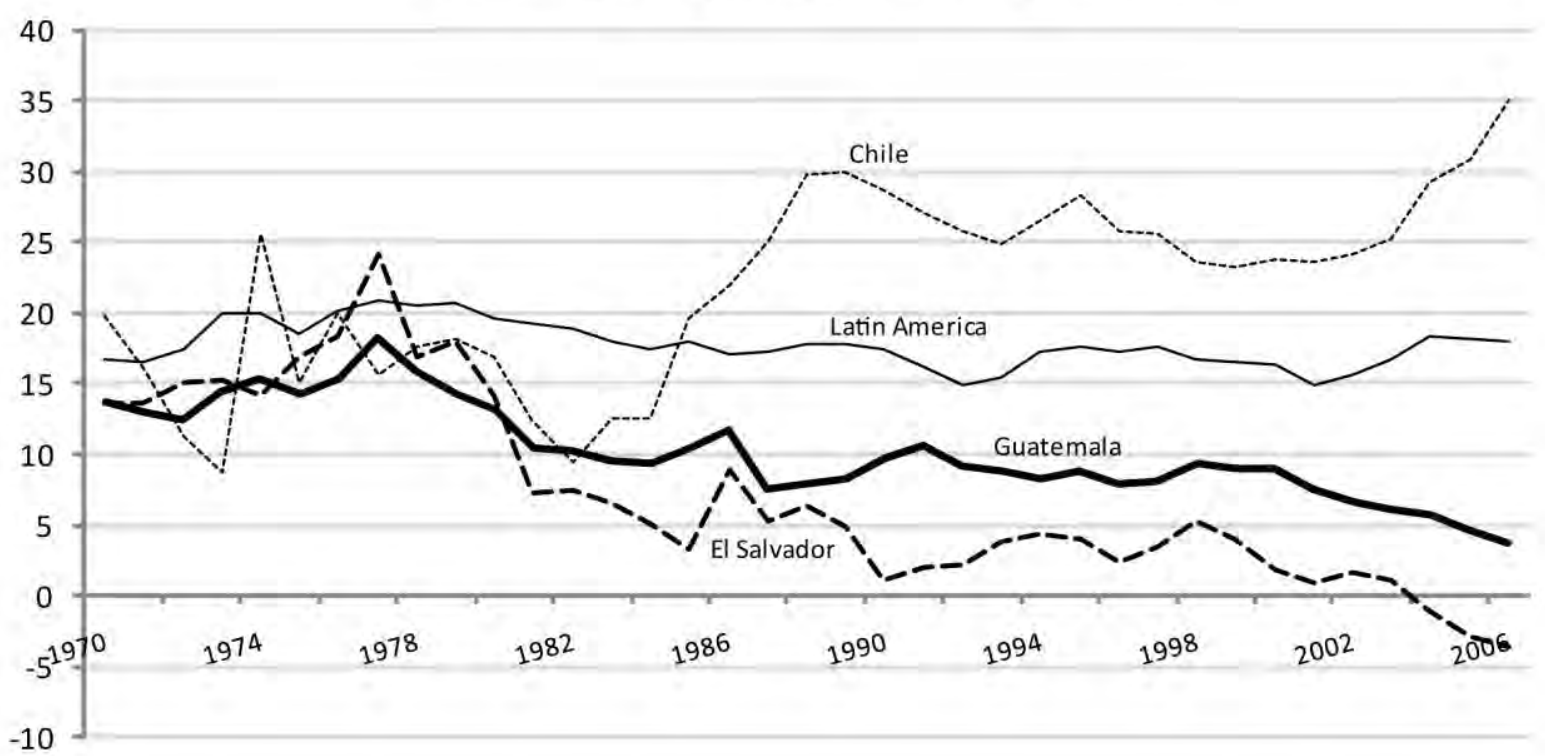

Like the catalyst crises seen before, the recent global financial crisis once again demonstrated the constraints on development imposed by holding low national savings ratios. Prior to this recent crisis, the absence of deep and liquid financial and capital markets in most Latin American countries induced large corporations to find sources of finance abroad with cheaper rates and better overall conditions. This was a natural development of globalization that benefitted local companies in the period from 2003-2007. But during the crisis, when international capital markets dried up, many corporations suffered serious constraints in access to finance. As a result, external debt default rates rose for corporations from Mexico and Brazil. Undoubtedly, in both booms and bust periods, Latin America's growth and development efforts would be in a better footing if the region enjoyed higher national savings ratios.

However, this is easier said than done since there is no consensus in the empirical literature regarding the direction of causality between national savings and economic growth. ${ }^{30}$ Notwithstanding this debate, it is important to differentiate between private and public savings.

\footnotetext{
${ }^{29}$ In the case of Central America, recent studies show that remittances have had a positive impact on private consumption, but an adverse effect on economic growth and savings. See, for example the paper by Cáceres and Saca (2006) for the case of El Salvador. Thus, in Central America, remittances add to other factors explaining low savings ratios.
} 
With regard to private savings, growth is an important determinant but it is not the only one. In many countries in the region, memories are still fresh regarding individuals' major losses in the real value of their wealth resulting from deep and recurrent financial crisis (see lesson 5 above). Regaining full credibility in the stability of the financial system takes a very long time, but is a necessary condition for private savings ratios to increase on a sustainable basis.

In addition, as explained in Loayza et al (2000), demographic differences also matter. High young-age dependency ratios (population younger than 15 years old as a percentage of workingage population) have a negative effect on private savings rates, and this can partly explain low private saving ratios in Latin America. Moreover Chile shows that a fully funded pension scheme allows private savings to increase without completely offsetting declines in public savings. However not many countries in the region have been able to successfully finance the fiscal cost of the transition to such a system, which requires support from general government revenues. The deep fiscal problem in Bolivia that resulted from the establishment of private pension funds is a case in point. Also, as coverage has remained extremely limited, private pension funds have not been able to induce increased savings for large segments of the population.

Improving public savings (the difference between government revenues and government spending) is a much more direct and accessible policy goal than increasing private savings. Before the crisis a number of Latin American countries had increased public saving by running primary fiscal surpluses. However as recognized in Birdsall et al (2008), efforts to improve public savings need to focus on improving the collection of taxes and on a better allocation of government expenditures. While financing the development needs of Latin America requires increased revenues, there is a minimum level of expenditure on the provision of public goods, especially in the social areas. Many countries in the region are below that minimum. The reader is directed to Birdsall et al (2008) for specific policy recommendations for improving tax systems in the region.

Lesson 8: Because the likelihood of large and unexpected international shocks will be there in the foreseeable future, multilateral organizations need to stand ready to provide liquidity to developing countries, including those in Latin America

In the period before the emergence of the international financial crisis, the International Monetary Fund (IMF) had significantly reduced its balance sheet. In 2006 Mervyn King, governor of the Bank of England, stated that the role of the IMF as a lender of last resort was going to become less and less important as corporations and governments were finding cheaper

\footnotetext{
${ }^{30}$ See Carroll and Weil (1993) and Gavin et al (1997) for evidence that growth causes savings and Gutierrez (2007) for mixed evidence about the direction of causality in Latin America. An important recent paper by Aghion et al (2009) provides theoretical background and empirical evidence showing that increased domestic savings might be needed to generate economic growth in developing countries that lag in the implementation of technological innovations. Their cross-country regression shows that lagged savings are positively associated with productivity growth in poor countries but not in rich countries.
} 
and larger sources of finance in the international capital markets. ${ }^{31}$ This view had achieved nearly consensus at the time. ${ }^{32}$ In Latin America, demand for new IMF resources had practically vanished. By end-2006, Uruguay, one of the smallest countries in the region, was the secondlargest IMF borrower (Turkey was the largest).

The global nature of the recent international financial crisis completely reversed views among the role of the IMF and other multilateral organizations. Large contagion from industrial to developing countries proved that, in a globalized world, full decoupling is almost impossible to achieve. This was certainly true in financially-open Latin America. As capital inflows, especially trade finance to the region dried up, the liquidity needs of many countries mounted. The extension of credit lines by the Fed to Brazil, Mexico and other emerging markets eased some of the liquidity constraints, but the IMF, the obvious institution for liquidity provision, was not ready. It lacked both the funding and the instruments. It was only in the second quarter of 2009 that the G-20 agreed to capitalize the IMF and that an adequate liquidity facility, involving fasttrack disbursement, the Flexible Credit Line (FCL) was created. Colombia and Mexico quickly applied to obtain this credit line.

An important lesson from the crisis is that the stability of the global financial system and that of Latin America needs the IMF as a lender of last resort and other multilateral organizations as complementary sources of funding. While essential (as explained in lessons 3 and 4), all type of self-insurance mechanisms (like accumulation of foreign exchange reserves and fiscal stabilization funds) as well as market-based insurances (such as contingent lines of credit with international banks or GDP-indexed bonds) might prove insufficient in the presence of a large adverse shock. As discussed above, the fundamental reason is that Latin America and the rest of developing regions do not issue hard, liquid currencies, but use them in financial and trade transactions. This feature is not going to change any time soon.

\section{Concluding Remarks}

The international financial crisis that erupted in developed countries in 2007 adversely affected all developing regions of the world; albeit with very different degrees of intensity. In contrast to previous crises episodes, Latin America fared relatively well: domestic banking systems remained stable and no runs against the local currencies took place. The crisis, however, exposed the strengths and weaknesses of the current paradigm of development in the region which is based on liberalized capital accounts and significantly improved macroeconomic conditions.

On the strength side, increased (but not pure) flexibility of exchange rates in the context of inflation targeting proved extremely valuable to ride the storm since--in sharp departure from the past--countries were in a position to lower interest rates and provide needed liquidity to firms when financing from the international capital markets dried up. Moreover, in the years before the crisis, the region understood that self-insurance mechanisms through the accumulation of foreign

\footnotetext{
${ }^{31}$ See, www.bankofengland.co.uk/publications/speeches/2006/speech267.pdf

${ }^{32}$ I, among others, was among those not subscribing to this view. See www.cgdev.org/content/opinion/detail/6438/
} 
exchange reserves and an improved term structure of external liabilities favoring longer maturities were essential tools for countries lacking the capacity to issue hard currencies.

On the weakness side, the crisis showed that two chronic maladies in the region, its lack of exports diversification and its very low savings ratios, attempt against the sustainability of Latin America's development model. While the former implied that the region was exposed to a sharp deterioration of the terms of trade at the peak of the crisis, the latter severely constrained the availability of domestic credit.

But beyond weaknesses and strengths, the crisis has opened up new issues and challenged some established beliefs in the region. Of particular importance are the role of the state during systemic crises generated abroad and the relevance of international financial regulations. During the crisis, a number of countries, including Chile (the best performer in the region), found out that, when adequately managed and fully funded, public banks can partially offset the sharp reduction of credit from private banks. It is however too early to derive long-term conclusions about this policy decision as the return to good times would need to be accompanied by a retrenching of credit activities by public banks to avoid crowding out of private sector financial institutions.

Regarding international financial regulations, many analysts in the region are now celebrating the slow pace taken by regulators in implementing Basel II, the newly proposed regulation for bank capital requirements. Basel II has been blamed as a major culprit for the eruption of the crisis in industrial countries. This paper has discussed a number of alternatives that Latin American countries can consider in designing regulations that are adequate for the degree of development of their financial systems. One can only hope that the G-20 and multilateral organizations take note of this experience and abandon the prevailing view that leveling the playing field in global financial markets implies similar financial regulations for countries regardless of their level of development. 


\section{References}

Aghion, Philippe, Diego Comin, Peter Howitt and Isabel Tecu. 2009. "When Does Domestic Saving Matter for Economic Growth?” Working Paper 09-80. Harvard Business School, Boston, Massachusetts. [http://www.hbs.edu/research/pdf/09-080.pdf].

Baggs, Jen, Eugene Beaulieu and Loretta Fung. 2008. "Are Service Firms Affected by Exchange Rate Movements?" Paper presented at the Midwest International Economic Meetings, May 1-3, University of Iowa, Iowa City.

Birdsall, Nancy, Augusto de la Torre and Rachel Menezes. 2008. Fair Growth: Economic Policies for Latin America's Poor and Middle-Income Majority, Washington DC: Center for Global Development and Inter-American Dialogue

Birdsall, Nancy and Liliana Rojas-Suarez. 2004 (eds). Financing Development: The Power of Regionalism, Washington DC: Center for Global Development.

Cáceres, Luis René and Nolvia N. Saca. 2006. "What do Remittances Do? Analyzing the Private Remittance Transmission Mechanism in El Salvador.” IMF Working Paper WP/06/250. International Monetary Fund, Washington, DC.

Carroll, C., and Weil, D. 1994. "Savings and Growth: A Reinterpretation", Carnegie-Rochester Conference Series on Public Policy. Vol. 40 (0): 133-92.

Chinn, Menzie D., and Hiro Ito. 2007. “A New Measure of Financial Openness”. La Follette School Working Papers. University of Wisconsin, Madison, Wisonsin.

Galindo, Arturo, Alejandro Izquierdo and Liliana Rojas-Suarez. 2009. "Financial Integration and Foreign Banks in Latin America: How do they Impact the Transmission of External Financial Shocks" (forthcoming) CGD Working Paper. Center for Global Development, Washington, DC.

Economic Commission for Latin America and the Caribbean (ECLAC). 2009. La Inversión Extranjera Directa en America Latina y el Caribe. Santiago de Chile: ECLAC.

Foxley, Alejandro. 2009. Recovery: The Global Financial Crisis and Middle-Income Countries, Washington DC: Carnegie Endowment for International Peace.

Goldstein, Morris. 2002. Managed Floating Plus. Washington, DC: Policy Analysis in International Economics 66. Institute for International Economics.

Gutierrez, Mario. 2007. "Savings in Latin America after the mid 1990s: Determinants, Constraints and Policies" Serie Macroeconomía del Desarrollo N0. 57. ECLAC, Santiago de Chile, Chile. [http://www.eclac.org/publicaciones/xml/9/27899/LCL2662_P.pdf]

Gavin, M; Hausmann R. and Talvi, E. 1997. "Saving Behavior in Latin America: Overview and Policy Issues". Working Paper R-346. Inter-American Development Bank, Washington, DC. 
International Monetary Fund. 2009. Regional Economic Outlook: Western Hemispher. Washington, DC.

Inter-American Development Bank. 2005. "Foreign Banks" in Unlocking Credit. Economic and Social Progress in Latin America, 2005 Report, 129-160. Washington DC.

Loayza, Norman, Humberto Lopez, Klaus Schmidt-Hebbel and Luis Serven. 2000. "Savings in Developing Countries: Overview”. World Bank Economic Review, Vol 14 91. World Bank. Washington, DC.

Rojas-Suarez, Liliana. 2009. ed. Growing Pains in Latin America: An Economic Growth Framework as Applied to Brazil, Colombia, Costa Rica, Mexico and Peru, Washington DC: Center for Global Development.

Rojas-Suarez, Liliana and Sebastian Sotelo. 2007. "The Burden of Debt: An Exploration of Interest Rate Behavior in Latin America" in Contemporary Economic Policy, Vol. 25, No. 3 (2007): 387-414.

Rojas-Suarez, Liliana.2004. "International Standards for Strenghtening Financial Systems: Can Regional Development Banks Address Developing Country Concerns?" In Financing Development: The Power of Regionalis, edited by Nancy Birdsall and Liliana Rojas-Suarez, 137 164: Washington DC: Center for Global Development.

Rojas-Suarez, Liliana. 2003. "Monetary Policy and Exchange Rates: Guiding Principles for a Sustainable Regime." In After the Washington Consensus: Restarting Growth and Reform in Latin America, edited by Kuczynski, Pedro Pablo and John Williamson, 123-155:Washington, DC: Institute for International Economics.

Rojas-Suarez, Liliana. 2001. "Can International Capital Standards Strengthen Banks in Emerging Markets?” Working Paper WP01-10. Institute for International Economics. Washington, DC.

Perry, Guillermo. 2009. "Beyond Lending: How Multilateral Banks can Help Developing Countries Manage Volatility.” Washington, DC: Center for Global Development.

Shixue, Jiang. 2001. "Evolution of the Latin American Development Models in the $20^{\text {th }}$ Century: Lessons and Implications for Other Developing Countries". Asian Journal of Latin American Studies. Volume 14. Issue number 1: 173-197.

Sanchez-Anochea. 2007. "Anglo-Saxon Structuralism vs. Latin American Structuralism in Development Economics." In Ideas, Policies and Economic Development in the Americas edited by E. Perez and M.Varengo, 208-227. Routledge, New York: Routledge Studies in Development Economics. 